\section{DIGITAL COMMONS @ UNIVERSITY OF SOUTH FLORIDA}

\section{ABO: Interactive Journal for Women in the Arts, 1640-1830}

Volume 1

Issue 1 Volume 1 (2011): Women's Poetry

Article 3

2011

\title{
Lady Mary's Imperfect Employment
}

Danielle Bobker

Concordia University, danielle.bobker@concordia.ca

Follow this and additional works at: https://digitalcommons.usf.edu/abo

Part of the Dramatic Literature, Criticism and Theory Commons, Educational Methods Commons, Feminist, Gender, and Sexuality Studies Commons, and the Literature in English, British Isles Commons

\section{Recommended Citation}

Bobker, Danielle (2011) "Lady Mary's Imperfect Employment," ABO: Interactive Journal for Women in the Arts, 1640-1830: Vol.1: Iss.1, Article 3.

http://dx.doi.org/10.5038/2157-7129.1.1.2

Available at: https://digitalcommons.usf.edu/abo/vol1/iss1/3

This Scholarship is brought to you for free and open access by Digital Commons @ University of South Florida. It has been accepted for inclusion in ABO: Interactive Journal for Women in the Arts, 1640-1830 by an authorized administrator of Digital Commons @ University of South Florida. For more information, please contact digitalcommons@usf.edu. 


\section{Lady Mary's Imperfect Employment}

\section{Keywords}

attribution, authorship, Jonathan Swift, Mary Wortley Montagu, print culture, satire, women's poetry

Creative Commons License

(c) (i) $\odot$

This work is licensed under a Creative Commons Attribution-No Derivative Works 3.0 License. 
The hawker shows you [the poem] in print,

As fresh as farthings from the mint:

The product of your toil and sweating;

A bastard of your own begetting.

-- Jonathan Swift, “On Poetry: A Rhapsody”1

When Cardinal Querini requests copies of her books for prominent display in his public library, Mary Wortley Montagu is offended, telling her friend and patron that she has never "printed a single line in [her] Life" (Selected 392). ${ }^{2}$ In a letter detailing the quarrel, Montagu explains to her daughter that she has been passive on principle when it comes to publication:

Sure no body ever had such various provocations to print as my selfe. I have seen things I have wrote so mangle'd and falsify'd I have scarce known them. I have seen Poems I never read publish'd with my Name at length, and others that were truly and singly wrote by me, printed under the names of others. I have made my selfe easy under all these mortifications by the refflection I did not deserve them, having never aim'd at the Vanity of popular Applause... (Selected 392)

Montagu understands that the corruptions associated with unauthorized editions - from local errors to outright misattributions - might be taken as "provocations to print" but she purposely renounces the control that could come with selling and publicly owning her writings. ${ }^{3}$ The cost to her sense of decorum and integrity would be too high. In fact, the messy, greedy print market has her within its grasp: her writings have made their way from manuscript to print; they have been sold and read and connected with her name. She even admits that she now objects less fervently when recognized as an author in Italy: "I confess I have often been complemented... on the Books I have given the Public. I us'd at first to deny it with some Warmth, but finding I persuaded no body, I have of late contented my selfe with laughing when ever I heard it mention'd...” (Selected 392) However she justifies her identification with the aristocratic - and obviously increasingly anachronistic - ideal of the closeted person of letters scribbling for her own pleasure and that of her intimate friends, on intentional grounds: she has "never aim'd at... popular Applause.” Another comment later in the same letter suggests it's not only nobility but femininity too that fuels Montagu's investment in this traditional ideal. She tells her daughter that there's a silver lining in female subservience: “The small proportion of Authority that has fallen to my share... has allwaies been a Burden and never a pleasure... I have allwaies thought corrections (even when necessary) as painful to the giver as to the Sufferer, and am therefore very well satisfy'd with the state of Subjection we [women] are placed in" (Selected 393). To be female is to be exempt from the pain of giving "corrections." It is telling that Montagu invokes the term commonly used in the period to refer to the process of copyediting a manuscript for publication: her authorial innocence is still on her mind.

Notwithstanding her significant output of poems, essays, and letters, and notwithstanding the urgings of several accomplished - and published - friends and acquaintances including Alexander Pope and Mary Astell, Montagu kept her distance from print throughout her life. ${ }^{4}$ Here her rationale for refusing to publish bears the stamp of her special brand of contrarian feminism. It echoes, for instance, her celebration of Muslim's women's full-body veil as an instrument of empowerment that, like a masquerade costume, "gives [women] the entire liberty 
of following their inclinations without discovery” (Turkish Embassy Letters 71). The social and cultural limitations women face in fact provide fertile soil for female self-definition: lemonade will be made from lemons. Yet Montagu's belief that attaching one's name to printed works would necessarily entail a loss or compromise for an author was by no means unique to her: many writers shared such concerns in a period of dramatic change in the socioeconomics of literary circulation. In 1694 the Bank of England had been founded, facilitating the flow of capital around the country. The following year Parliament had allowed the Printing and Licensing Act to lapse: both the state and the booksellers' guild, known as The Stationers' Company, lost their official jurisdiction over not only which books were made and sold, but also where, how, and by whom. A commercial publishing industry soon began to flourish. By 1705, the number of printers in London had nearly tripled..$^{5}$ As Margaret Ezell, Harold Love, Paula McDowell, and others have pointed out, what we would now call print culture did not emerge in a single decade. Montagu was one of many eighteenth-century authors - particularly poets, aristocrats, and women - who continued the dominant practice of the previous century: authorizing only the manual transmission of her writings, she subscribed to a traditional system of literary value which held that fame rhymed with shame, that it was the quality, not the quantity, of one's readers that mattered. However, the success of the print trade was changing the terms of all textual production, not least because there was nothing to stop publishers from printing and selling any manuscript that came their way.

This essay will argue that Montagu's pose of willful passivity with respect to print and her awareness of the archaism of her position given the development of the publishing industry are central to "Reasons that Induced Dr S[wift] to write a Poem call'd the Lady's Dressing room," which she wrote within two years of the appearance of Jonathan Swift's most famous scatological poem. In Swift's poem, Strephon takes an illicit, and too intimate, tour of Celia's toilet, which concludes when he reaches into a chamber pot that has been disguised as a pretty cabinet. In Montagu's poem, Dean Swift shames himself sexually then proposes to get revenge on his lover by publishing an obscene description of her chamber. Since Robert Halsband introduced it in 1970, other critics have tended to agree with him that in imagining Swift's poem's fictional origins, Montagu particularly targeted its misogyny. ${ }^{6}$ Certainly the title of Montagu's poem, which borrows from a formula used by early eighteenth-century political pamphleteers ("Reasons that Induced"), promises an ideological critique of some kind (Lady Mary 343). However, as I read it, the battle of the sexes Montagu stages is entangled in and ultimately subordinated to her critique of the print market: layered allusions to classical, seventeenth- and eighteenth-century poetry at once shape her attack on Swift's conflicted relation to commercial authorship and ultimately shed light on her own evasive dance with publicity and publication. Now widely anthologized, Montagu's poem is known as one of the most energetic expressions of antipatriarchal outrage in the early eighteenth-century canon. I aim not so much to challenge as to nuance this reputation by shifting attention to the poem's sophisticated formal engagement with a set of issues as close to Swift's heart as her own.

Though Montagu imitates the broad octosyllabic couplets and the urban grit of Swift's mockpastoral, she replaces his dressing-room-tour-as-cure-for-love theme with another neoclassical motif: ${ }^{7}$ that of the imperfect enjoyment. ${ }^{8}$ Having roots in Book 3 of Ovid's Amores and Petronius's Satyricon, the satirical narrative of male sexual dysfunction had been revived by Rémy Belleau in sixteenth-century France, then translated or revised by a handful of English 
Restoration poets including Aphra Behn, George Etherege, and the Earl of Rochester. ${ }^{9}$ Montagu repeats the basic plot of the imperfect enjoyment, or disappointment: after her Doctor Swift finally gains access to his beloved Betty’s “bower," he "tries - and tries” to please her as a lover but discovers that he is impotent, and this makes him angry. Yet, focusing in particular on how a new era of economic opportunism affects experiences of authorship and erotic embodiment, Montagu adapts the mock-pastoral convention in several significant ways.

Typically the swains in impotence poetry are quickly enflamed and aggressive. Behn's “Amorous Lysander,” for instance, is “by an Impatient Passion sway'd” (2), Rochester's speaker "clasp[s]" his lover in "longing Armes" (1). Etherege's lover makes a first move that his "enemy” must resist "with pleasing force” (qtd. in Braudy 182). Montagu's Swift is anything but. He's slow and fussy, a fop. He "stalks" (5) down a London street in a "clean, starch'd Band" (1), flaunting his diamond ring and a "Golden Snuff-box" (2). ${ }^{10}$ This opening portrait conflates Swift's pretentious tobacco habit with Dublin's Freedom of the City in a gold box, the citizenship award he'd received in 1730 . It was reputed that, while clamoring loudly for the prize over a period of three years, Swift had already composed an inscription for the box: to "the most eminent patriot and greatest ornament of this his native city and country" (Ehrenpreis 651; Kelly 80). A prissy appetite for approval defines Montagu's Dean's seduction style too. He first tries to impress Betty with verbal tricks -- joking, punning, swearing (9) -- then resorts to anecdotes about the "part he bore / In OXFORD's Schemes in Days of yore” (11-12) - that is, his shortlived career, two decades before, as a Tory propagandist. Thus, well before any sexual contact with Betty, Swift's masculinity appears damaged - not by an excess of testosterone, but rather by his too cerebral and self-conscious pursuit of public recognition.

For her part, Betty, Swift's beloved, as the British name signals, is no Arcadian maiden, but the servant to Celia, the absent lady of “The Lady's Dressing Room.” Betty's intimacy with the Dean is as forced as his with her, though far less romanticized. In traditional impotence poetry, nymphs comply sexually because they can’t help themselves. Ovid's Corinna "pressed / Her thighs up snug under [his] [and] plied [him] with sexy kisses / Tongue exploring like mad" (7: 810); Rochester's Corinna "clipps [him] to her Breast and sucks [him] to her face” (6); Etherege's beloved "seem[s] to guide [his hands] to the fought-for place" (qtd. in Braudy 183); even Behn's coy nymph "wants the pow'r" to say no (20). In Montagu's parody, Jenny the maid informs the Doctor that to gain access to her mistress he need simply pay four pounds (18). The significance of this payment appears to go over his head. He represents the payment for services-to-berendered in the language of chivalry: "The destin'd Off'ring now he brought, / And in a Paradise of Thought; / With a low Bow approach'd the Dame, / Who smiling heard him preach his Flame" (21-24). Betty's smile is barely repressed laughter, and it is the "destin'd Off'ring" not the Dean's verboseness that "convinces” (26) her of his attraction to her. When the gold is securely locked away (27), she returns in a state that the speaker has Swift interpret as "blushing Grace" (29) -- presumably naked and ready to go, given that he will soon "peep" (69) at her breasts "with surprise" (68). Prostitution was a very flexible category in the eighteenth century, subsuming all forms of extramarital sexuality. Montagu is careful to specify that Betty is drawn to Swift not by carnal desire or political ambition, either of which would qualify her for the elevated subcategory of courtesan, but by bare economic self-interest. As Laura J. Rosenthal has recently argued, common fears of the psychological effects of "navigating the radically unstable financial world with only the body’s labour and imagination’s capacity as resources” were 
exemplified in the figure of the whore whose obsession with money destroyed all her other passions and interests (Infamous 75). Swift's contract with Betty situates their relationship squarely within the realm of commerce.

In the imperfect-enjoyment tradition, men externalize their anger immediately following impotence or premature ejaculation: embodiment, it turns out, is a bitch. Following Ovid and Petronius, Rochester has his speaker chastise his own objectified penis at length - "Thou Treacherous, base Deserter of my Flame” (46). Women's bodies are generally made to take the fall - for attracting men too much: Behn's swain blames the "Shepherdess's Charms" (138), as does Etherege's in a roundabout way, telling his nymph, "You'd been more happy had you been less fair” (qtd. in Braudy 184). Rochester's speaker holds Corinna at least partly responsible: “A touch from any part of her had done't: / Her hand, her foot, her very look's a Cunt” (17-18). By contrast when Montagu's Doctor Swift gets mad, his object is economically rather than physically material. Though he has up till now feigned ignorance of it, at the moment of his impotence it is revealed that he is all too aware that his connection to Betty is founded on exchange: "The Ev'ning in this hellish Play / Besides his Guineas thrown away, / Provok'd the Priest to that degree, / He swore..." (70-73). Indeed the "Rev'rend Lover" (67) is unable to sustain his façade of courtship through a single sentence: "With all my Heart, I'll go away," he tells Betty, "But nothing done, I'll nothing pay: / Give back the Money” (82-84). There's a subtextual pun here: if the Dean cannot spend - ejaculate - then why must he spend his guineas? For all Swift's old-fashioned foreplay, even mock-pastoral vestiges of sensuality are gone. He can conceive of his sexual loss only in the abstract quantitative terms of the marketplace.

Disappointment generally makes rakes think - about the vexed relationship between the mind and the body, between desire and love, about the possibility that their much-vaunted pleasure principle is as naïve as the Petrarchan ideals they consciously reject. This turn to discourse brings a different (implicitly better) form of satisfaction. The energy Rochester's speaker gets from spewing venom at himself and Corinna clearly has some sort of compensatory effect. Ovid's speaker even finds himself getting aroused - "Yet now - what perverse timing! -- just look at it, stiff and urgent, / Eager to go campaigning, get on the job” (7: 67-68) - as he remembers his impotence in verse. And disappointment makes rakes want to write. With respect to this sense that the body's mechanical failures might be redeemed through language, the Dean is not unlike his frustrated forefathers. ${ }^{12}$ But the crassly public linguistic production the Dean proposes is decidedly un-rakish. He yells at Betty: "I'll be revenged you sawcy Quean... / I'll so describe your Dressing-Room, / The very Irish shall not come” (96, 98-99). During the Restoration, poetry in general had been almost exclusively an aristocratic genre, and the imperfect enjoyment was the mode par excellence of the libertine-wit writing for the amusement of friends and acquaintances. As they circulated in and around Whitehall Palace, witty accounts of heterosexual humiliation especially bolstered the homosocial relationships that were most crucial to success at court. The printed “description” Montagu's Swift imagines writing hinges on a modern textual economy in which reputation, revenge, and success have calculable values. At the very least he wants to slander Betty and thus to spoil her earning potential. Ideally, he also wants to recover the four pounds he has "lost" through the unfulfilled contract. Swift's aim to ensure that his description of Betty's dressing room will put off the "very Irish" points to the wide audience he hopes to reach and is suggestive of more starkly instrumental author-reader relations than those cultivated and nurtured by manuscript circulation. The Anglo-Irish Dean 
doesn't respect true Irishmen - Betty's chamber is going to have to sound really disgusting if he is going to perturb these foul people. Nevertheless he is prepared to adjust his discourse indeed, even to lie - in order to get the attention of members of the lowest sphere of society since this will help his cause. In this way, Montagu evokes Swift's complicated attachment to the people of his home and native land and, at the same time, efficiently caricatures the inclusivity of commercial print publics.

At the end of her poem, Behn points in passing to a hidden well of female rage when the speaker mentions that she identifies with the young woman whose sexual misadventures she has been narrating in the third person: “The Nymph's Resentments none but I / Can well Imagine or Condole” (131-32). In Montagu's poem, for the first time in the history of the form, several female subjects openly speculate about the causes of male sexual dysfunction. Having "grown furious” (78), Betty's response is direct. To Swift's threat of slander, Betty counters: "What if your Verses have not sold, / Must therefore I return your Gold? / Perhaps you have no better Luck in / The Knack of Rhyming than of [fucking]” (90-93). Given the date of the poem's composition, the jibe about Swift's verses not selling may refer to the multiple calls for subscriptions to a multi-volume collection of writings by "Dr S" that had appeared in the Dublin Journal since early in 1733. To be published in Ireland by George Faulkner, this solo venture represented a turning point in Swift's career, but, as Stephen Karian has demonstrated, he felt a good deal of ambivalence about it. On the one hand, he knew he was dissatisfied by the multivolume, multi-author collections whose publication his friend, Pope, had recently directed in London: in the Miscellanies (1727-1732), authorship was unattributed, royalties were nonexistent, and the selection and editing processes were entirely out of his hands. He would have more control working with a local bookseller like Faulkner. On the other hand, Swift wasn't thrilled to be publishing in Ireland. A London edition of his own would have been much more prestigious, but all his efforts to strike a deal with publishers based in the capital had failed. For two years, the date of the first Faulkner edition was repeatedly announced then delayed, and in letters to friends written throughout this period Swift often implied that Faulkner was launching the series without his permission (Ehrenpreis 779-90 and Karian 30-43). Betty's retort invokes the new system of values to which Swift becomes subject, whether he likes it or not, when entering the volatile print market: popular appeal and the bottom line are the only measures of poetic success recognized by a bookseller. Betty makes impotence a figure for the risks of doing business. Sexual satisfaction at "Sixty odd" (79), like writing bestselling rhymes, requires a man to have not only a certain "Knack" but also "Luck" (93, 92), that arbitrary mistress, on his side.

Montagu's speaker offers another explanation of Swift's authorial and sexual failures, which she couches in moral maxims mid-way through the poem. In her "small Digression” (34), Montagu sketches a normative counterpoint to the marketplace values the poem satirizes. The prostitute Betty focuses on the salability of Swift's verses, which she believes depends, at least in part, on his good fortune. In the speaker's “noble Thoughts” (63), talent (or the lack thereof) is the main concern, and it is nature alone, especially in the classical sense of capacities innate in birth and blood, that determines it. Montagu's digression imitates a trope from Horace that Swift had recently reworked in "On Poetry: A Rhapsody": "Brutes find out where their talents lie: / A bear will not attempt to fly... / But man we find the only creature / Who, led by Folly, combats Nature..." (13-14, 19-20). ${ }^{13}$ For Swift, "talent” is a manifestation of "Nature” that dictates what 
it is appropriate for each living thing to do. Human beings are the only creatures so stupid as to try to fight this force, and he will go on to specify that, among men, those who write poetry with an eye to personal gain - whether of patronage, fame, or money - are the most foolish of all. Montagu’s digression subtly recasts nature in traditional social-hierarchical terms:

Alas! for wretched Human-kind, With Wisdom mad, with Learning blind, The Ox thinks he's for Saddle fit, (As long ago Friend Horace writ;) And Men their Talents still mistaking, The Stutterer fancys his is speaking... ...The Beau affects the Politician,

Wit is the Citizen's Ambition...

None strive to know their proper Merit, But strain for Wisdom, Beauty, Spirit.

Nature to ev'ry thing alive,

Points out the Path to shine or thrive, But Man, vain Man, who grasps the whole, Shows in all Heads a Touch of Fool; Who lose the Praise that is their due, While they've th'Impossible in view...

Instinct the Hound does better teach, Who never undertook to preach;

The frighted Hare from Dogs does run, But not attempts to bear a Gun- (35-40, 43-44, 49-56, 59-62)

The implication is that Swift, like the stuttering orator, political beau, and would-be wit, is a misfit who has failed to recognize his "proper Merit" (49). On the one hand, the Dean has "strained" basely: his scatological impulses and attention to a common whore are grotesque repudiations of "Wisdom, Beauty, Spirit." On the other hand, and worse, his affectations - his poetry and other strategies for self-promotion, the pristine clothing, and fussy manners represent an "Impossible" upward strain: they are vain (both pompous and futile) attempts to exceed the social sphere he was born to occupy. "Nature to ev'ry thing alive, / Points out the path to shine or thrive," the speaker insists. The Dean can neither "shine" nor "thrive" because he has strayed from the path appropriate to his low blood and, to a lesser extent, his age. The "Path... to thrive" also refers to the middle path, the classical ideal of moderation, which is obscured by the Dean's various aspirations, and also, slyly, to Betty's vagina, which he will never penetrate. Via Betty, Montagu makes the specter of Swift's limp phallus into a satirical symbol of the contingencies of the print market; in the speaker's oblique attack, impotence conjures the inevitable failures of a lowborn man who tries to transcend his proper place. Not only is Swift not entitled to public status, a burden that Montagu, as a woman, shares with him, unlike her he is naturally talentless in poetry. ${ }^{14}$

But Montagu cuts deepest with a pointed allusion to “The Lady’s Dressing Room.” The Dean blames his impotence on the smell of Betty's chamber (74-77). After he demands a refund of his four pounds, Betty challenges: “I’ve lock'd it in the Trunk stands there, / Go break it open if you 
dare” (86-87). Montagu's title positions the speaker and her readers in an impossible, circular moment that is at once chronologically prior to the writing of "The Lady's Dressing Room" and at the same time fully aware of its content. Recalling Swift's poem now, we take it as his acceptance of Betty's challenge - and yet another misfire. With Betty's challenge, Montagu retrospectively rewrites the whole of Swift's poem as a nightmarish repetition of this earlier disappointment, in which, seeking retribution for his sexual humiliation, Swift's alterego, Strephon, "dares" to penetrate the trunk in his beloved's boudoir only to face a further and greater humiliation. At the (anti)climax of the "revenge" poem, Strephon's discovery that "Oh! Celia, Celia, Celia shits!” (118) traumatizes him. Forever thereafter "[h]is foul imagination links / Each dame he sees with all her stinks / And, if unsavoury odours fly / Conceives a lady standing by" (121-24). Appropriating and redirecting the associative disorder depicted in "The Lady’s Dressing Room,” Montagu has the Dean mistake his own guineas for human waste. One dirty secret has been joined by "foul Imagination" (121) to another. Thus Strephon's fear of women's bodily materiality (which is not far from the misogynist anger of disappointed Restoration rakes) is in fact a displacement of Swift's fear of the economic calculus to which he has reluctantly made himself subject - in particular, his fear of the exchange value that creates equivalences between utterly disparate things, like gold coins, sex acts, and his poetry. Betty and the speaker mock Swift's efforts to gain public renown through his poetry, but the poem's more scathing abuse lies in the anxiety over marketplace transactions attributed to the writer himself.

As Montagu well knew, the critique of print culture and self-satire were both specialties of Swift's. His mock-treatise, Tale of a Tub, was one of the earliest texts to warn against the political and religious dangers posed by the lapse of the Licensing Act, and his poem, "On Poetry: A Rhapsody,” cited above, narrates the progress of a modern poem from inspiration and composition to publication and public reception as an absurd and degrading waste of time that scars the poet for life. The lines in my epigraph portray the modern poet's profound sense of alienation when first encountering his work in public - in this case, in the hands of a street hawker. The poem is as "fresh as farthings from the mint" because the commercial context of its publication likens it to paper currency. ${ }^{15}$ And it is a "bastard" because to get it published the poet has had to form an unholy alliance with the bookseller. "On Poetry" circulated widely both in manuscript and in a tamer print version throughout Swift's lifetime (Karian 103-32). In his personal parodies, Swift made his suspicious fascination with public recognition - Had he achieved it? Did he desire it? What did it signify? - central to his authorial persona, and regularly exploited the cultural tensions between manuscript and print to do so. ${ }^{16}$ One vivid example is the media event surrounding his poem "The Life and Genuine Character of Dr Swift." While he was composing it between 1731 and 1733, he staged a hoax that capitalized on the reputation of a longer manuscript poem on the same subject called "Verses on the Death of Dr Swift." In both works, friends and acquaintances give mean-spirited or trite posthumous assessments of Swift's contributions to British letters. First in the Dublin Journal there was an announcement "we have reason to believe [that the true copy of a certain poem] will be published in a few days, to the great delight and entertainment of the world, and probably equally to the vexation of the author...” (qtd. in Ehrenpreis 709); the newer poem was published, and then there was another announcement in which Swift denied having written it. ${ }^{17}$ Betty's parting blow in Montagu's poem - "I'm glad you'll write, / You'll furnish Paper when I Sh[it]e” (100-01) - invokes a popular trope of the period that exploded the idea of literary exchange value by imagining printed pages reduced to their basic (material) use value, a trope that Swift also employs, for 
instance, when, in his poem "Drapier’s Hill," he pictures his own "famous Letters" - the influential political treatises he wrote in the voice of an Irish drapier - "made waste paper" (17). In another personal parody, a mock-country-house poem written to circulate among friends called "Panegyric on the Dean," Swift explores how the demise of communal ideals affects experiences of all kinds of physical and mental labour - whether writing a poem, ejaculating, or defecating - and the cultural value of these "products.” As Ann Cline Kelly has argued, commenting on the changing media culture of the early eighteenth century was not merely an intellectual exercise for Swift. He was a brilliant media performer: circulating different versions of his writing via multiple channels and often advertising this multiplicity, he tested the shifting registers of meaning, modes of authorship, and textual relations associated with manuscript and print.

If, as critics often suggest, Montagu was hoping to beat Swift at his own game, there are at least three ways to construe the success of "Reasons that Induced Dr S[wift] to write a Poem call'd the Lady's Dressing room.” First: formally. Though Montagu appropriates many of Swift's moves and motifs, she puts them in the service of her original modernization of the imperfect enjoyment, a mode of mock-pastoral that he had largely neglected. Second: psychologically. Swift sometimes represents himself as desperate for admiration but never for money; and Judith Mueller has observed of his few late-career experiments with the imagery of phallic failure in particular that "Swift treats his impotence as an advantage" (59), since, on the literal/physical level, it shores up his preferred role as a discipliner of women's erotic desires, and, as a symbol of linguistic incompetence, it cleverly masks his real rhetorical power. Montagu's representation of Swift's paranoid and ineffectual complicity with print commerce is much less flattering and much less forgiving than anything in his self-satire. Finally, the poem's own circuitous path to publicity opens up a third way to reckon Montagu's out-Swifting of Swift. The poem was published - without attribution - shortly after she wrote it. Isobel Grundy notes that it is unclear whether Montagu or someone else arranged for the poem's printing since Montagu's fair copy, which she excluded from the album of works that she regularly shared and acknowledged as her own, was significantly different from the first published version ("Lady Mary" 342-43). Even if she was not actively involved, Montagu must have predicted that her lively treatment of a hot topic would not long be constrained within close circles, that if irresistible enough her closet experiment would be propelled into print. Indeed Montagu probably hoped to make readers suspect that Swift, whose career she obviously followed attentively, was the author of her satire. ${ }^{18}$ Performed as if inadvertently before a large audience, such a disappearing act would be both a classically Swiftian gesture and a powerful public affirmation of her elite female entitlement to authorial privacy.

Recently feminist literary scholars have begun looking to complicate the critical approaches to eighteenth-century women's writing developed four decades ago when efforts to expand the canon first became widespread. We are "recovering from recovery," as Rosenthal puts it. ${ }^{19}$ She observes that because certain women writers "were brought into the canon at a particular time and through the lens of particular questions, we still have much to learn beyond those initial inquiries” (10). Paula R. Backscheider proposes that though we should continue to account for the different (often limited) resources available to women writers, greater attention must be paid to their agency in all its complexity - to their inventiveness on the page and their ingenious modes of self-definition in the world of letters and beyond it. In particular, Backscheider hopes 
we can move away from an earlier mode of critique focused on sexism and fueled by anger: "To seek and privilege anti-patriarchal themes falsifies women's - and human - literary history," she writes, "and while I give the theme of defiance its due, I believe that emphasis on it has been almost as much a detriment to assessment as trivialization” (xvi). For both Backscheider and Rosenthal, Mary Wortley Montagu is a prime example of a female writer who has at once benefited from and been boxed in by the recovery project. ${ }^{20}$ At first glance, "Reasons that Induced Dr S[wift] to Write a Poem Call'd the Lady’s Dressing Room” has seemed to many critics to epitomize and authorize defiance feminism, and the fact that it has done so has almost certainly facilitated its (and Montagu's) fast and smooth assimilation into the new eighteenthcentury canon. ${ }^{21}$ In this essay, I have tried to point out some of the subtleties that this characterization obscures. I have argued that Montagu reworked the imperfect enjoyment tradition with an eye to Swift's oeuvre in an effort to create an innovative and apt lever for the expression of her aristocratic distaste for the print market - and perhaps also to lay claim to anonymity, that toehold in the chaos of media shift, as the prerogative of the noblewoman writer above all. In the period since the recovery project began, scholars have looked at "The Lady's Dressing Room” through an amazing variety of formal, cultural, historicist, psychoanalytic, and feminist lenses; Montagu's reply to Swift deserves, and will reward, the same. 
Notes

1. Lines 113-116. Hereafter line numbers in parentheses will follow all citations of poetry.

2. I wish to thank the many readers whose comments and questions have contributed to this argument at various stages, including Michael McKeon, Kathryn Steele, Kathy Lubey, Meredith Evans, Omri Moses, Jonathan Sachs, Marcie Frank, Laura Runge, and Kirsten Saxton.

3. For another discussion of this passage, and of Montagu's aristocratic views of authorship in general, see Robert Halsband, Life 255.

4. In "The Politics of Female Authorship,” Isobel Grundy analyzes some of Montagu's written responses to the appearance of her works in print, arguing that personal and political conflicts "made her too insecure to accept willingly the role of published poet” (37).

5. Citing Michael Treadwell and James Raven respectively, Paula McDowell observes that "while the Printing Act had tried to limit the number of master printers in all of England to twenty-four, by 1705 there were between sixtyfive and seventy printing houses in London alone" and "by 1800, print issued from hundreds of presses operating in London and almost every small town in the country” (234).

6. For readings of the poem focusing on Montagu's frustration with Swift's sexism, see Halsband, "Ladies of Letters” 42 and “"The Lady's Dressing Room'”; Grundy, Lady Mary Wortley Montagu 342-44; and Alison Winch. Notes introducing or accompanying Montagu's poem in anthologies also often either state or imply that misogyny is Montagu's major concern: see, for instance, British Literature 768, Meridian Anthology 217, and Norton Anthology 2593.

7. As Peter J. Schakel points out, “The Lady's Dressing Room” alludes to Ovid’s Remedia Amoris in which Phineus is advised that watching his mistress putting on her make-up will cure his excessive passion for her.

8. Most critics recognize Montagu's sharp mimicry of Swift's style and imagery. Emphasizing the innovation in her imitation, my argument builds on Grundy's passing observation that "Montagu follows Rochester and Behn in her treatment of impotence" (Lady Mary 343).

9. My generalizations about imperfect enjoyment draw on classical and neoclassical poetry and prose as well as criticism by Leo Braudy, Carole Fabricant, Richard Quaintance, Reba Wilcoxon, and Lisa M. Zeitz and Peter Thoms.

10. My essay refers to the version of the poem first published by T. Cooper in February 1734 under the title "The Dean's Provocation For Writing the Lady's Dressing-room” which Halsband reproduces in “"The Lady's DressingRoom' Explicated by a Contemporary." This early print version of the poem is slightly longer than those in extant manuscripts in the Montagu archive: a publisher or someone else may have added one or more lines. In Essays and Poems 273-5, especially 273 and 275, Grundy and Halsband discuss the differences between various early versions of the poem and the date of its composition (Montagu, "The Reasons").

11. See Irvin Ehrenpreis 650-55.

12. See, for example, Braudy 188 and Zeitz and Thoms 511-12.

13. See the last lines of Horace, Epistles 1.14.

14. On Montagu's snobbery and its impact on her attitude toward Swift and Alexander Pope, see Halsband, Life 255-6 and Margaret Anne Doody: both cite the letter in which Montagu sneers, "These two superior Beings were entitl'd by their Birth and hereditary Fortune to be only a couple of Link Boys.”

15. Catherine Ingrassia has explored at length the impact on eighteenth-century authorship of the close imaginative connection between printed text and paper credit. 
16. See Ann Cline Kelly, Jonathan Swift and Popular Culture.

17. See Ehrenpreis 708-13 and 756-07.

18. Shortly after the publication of "The Lady's Dressing Room," “A Modest Defense of a Late Poem Call'd 'The Lady’s Dressing Room” appeared. This prose tract, which upheld the decency of the "Hibernian Bard,” was probably written by Swift himself to stir up controversy over his poem. See Halsband, “"The Lady's Dressing Room"” 225.

19. "Recovering from Recovery" is the title of Rosenthal's introduction to the recent special issue of Eighteenth Century: Theory and Interpretation on "The Future of Feminist Theory in Eighteenth-Century Studies."

20. See Rosenthal, “Introduction” 9-10 and Backscheider 83-99, especially 84.

21. Of this poem and Montagu's letter on the Turkish baths, Rosenthal remarks that "it sometimes seems, searching through the MLA bibliography, that [Montagu] really only wrote one letter and one poem” (9). 


\section{Works Cited}

Backscheider, Paula R. Eighteenth-Century Women Poets and Their Poetry: Inventing Agency, Inventing Genre. Baltimore: Johns Hopkins UP, 2005. Print.

Behn, Aphra. “The Disappointment.” Works of Aphra Behn: Poetry. Ed. Janet Todd. Vol. 1. London: Pickering, 1992. 65-69. Print.

Braudy, Leo. "Remembering Masculinity: Premature Ejaculation Poetry of the Seventeenth Century.” Michigan Quarterly 33.1 (1994): 177-201. Print.

Doody, Margaret Anne. “Swift among the Women.” Critical Essays on Jonathan Swift. Ed. Frank Palmeri. New York: Hall, 1993. 13-37. Print.

Ehrenpreis, Irvin. Swift: The Man, His Works, and the Age - Volume III: Dean Swift. Cambridge: Harvard UP, 1983. Print.

Ezell, Margaret. Social Authorship and the Advent of Print. Baltimore: Johns Hopkins UP, 2003. Print.

Fabricant, Carole. “Rochester’s World of Imperfect Enjoyment.” Journal of English and Germanic Philology 73.3 (1974): 338-50. Print.

Grundy, Isobel. Lady Mary Wortley Montagu. New York: Oxford UP, 1999. Print.

---. “The Politics of Female Authorship: Lady Mary Wortley Montagu's Reaction to the Printing of Her Poems.” The Book Collector 31.1 (1982): 19-37. Print.

Halsband, Robert. The Life of Lady Mary Wortley Montagu. New York: Oxford UP, 1956. Print.

---. "Ladies of Letters in the Eighteenth Century.” The Lady of Letters in the Eighteenth Century. Eds. Irvin Ehrenpreis and Robert Halsband. Los Angeles: William Andrews Clark Memorial Library, U of California P, 1969. 31-51. Print.

---. “'The Lady’s Dressing Room' Explicated by a Contemporary.” The Augustan Milieu: Essays Presented to Louis A. Landa. Ed. Henry Knight Miller, Eric Rothstein and G.S. Rousseau. Oxford: Clarendon, 1970. 225-31. Print.

Horace. "Epistle I.” The Odes, Epodes, Satires, and Epistles, Translated by the Most Eminent English Scholars and Poets. New York: Warne, 1889. 289-93. Print.

Ingrassia, Catherine. Authorship, Commerce and Gender in Early Eighteenth-Century England: A Culture of Paper Credit. New York: Cambridge UP, 1998. Print.

Karian, Stephen. Jonathan Swift in Print and Manuscript. New York: Cambridge UP, 2010. Print.

Kelly, Ann Cline. Jonathan Swift and Popular Culture: Myth, Media, and the Man. New York: Palgrave, 2002. Print.

Love, Harold. "Early Modern Print Culture: Assessing the Models.” The Book History Reader. Eds. David Finkelstein and Alistair McCleery. New York: Routledge, 2006. 74-86. Print.

McDowell, Paula. "Mediating Media Past and Present: Toward a Genealogy of 'Print Culture' and 'Oral Tradition.” This is Enlightenment. Eds. Clifford Siskin and William Warner. 229-246. Chicago: U Chicago P, 2010. http://dx.doi.org/10.7208/chicago/9780226761466.003.0012

Montagu, Lady Mary Wortley. Selected Letters.Ed. Isobel Grundy. London: Penguin, 1997. Print. 
---. “The Dean’s Provocation for Writing the Lady’s Dressing-Room.” Halsband. 228-31.

---. “The Reasons that Induced Dr S[wift] to Write a Poem Call'd the Lady's Dressing Room.” Essays and Poems and Simplicity, A Comedy. Eds. Robert Halsband and Isobel Grundy. Oxford: Clarendon P, 1977. 273-76. Print.

---. "The Reasons that Induced Dr S[wift] to Write a Poem Called the Lady's Dressing Room.” British Literature, 1640-1789: An Anthology. Ed. Robert Demaria, Jr. Malden, MA: Blackwell, 1996. 768-9, 779-81. Print.

---. “The Reasons That Induced Dr S[wift] to Write a Poem Called the Lady's Dressing Room.” The Norton Anthology of English Literature. Volume C: The Restoration and the Eighteenth Century. Eds. Lawrence Lipking and James Noggle. New York: Norton, 2006. 2593-95. Print.

---. “The Reasons that Induced Dr. S[wift] to Write a Poem Called 'The Lady’s Dressing Room.'” The Meridian Anthology of Early Women Writers: British Literary Women from Aphra Behn to Maria Edgeworth, 16601800. Eds. Katharine Rogers and William McCarthy. New York: New American Library, 1987. 217-19. Print.

---. Turkish Embassy Letters. Ed. Malcolm Jack. Athens: U Georgia P, 1993. Print.

Mueller, Judith. "Imperfect Enjoyment at Market Hill: Impotence, Desire, and Reform in Swift's Poems to Lady Acheson.” ELH 66.1 (Spring 1999): 51-70. Print. http://dx.doi.org/10.1353/elh.1999.0008

Ovid. The Amores: Book 3. The Erotic Poems. Trans. Peter Green. New York: Penguin, 1992. 137-65. Print.

Petronius. The Satyricon. Petronius, The Satyricon and Seneca, The Apocolocyntosis. Trans. J.P. Sullivan. New York: Penguin, 1986. Print.

Quaintance, Richard. “French Sources of the Restoration 'Imperfect Enjoyment’ Poem.” Philological Quarterly. 42 (1963): 190-99. Print.

Rochester, John Wilmot, Earl of. “The Imperfect Enjoyment.” The Works of John Wilmot, Earl of Rochester. Ed. Harold Love. Oxford: Oxford UP, 1998. Print.

Rosenthal, Laura J. Infamous Commerce: Prostitution in Eighteenth-Century British Literature and Culture. Ithaca, NY: Cornell UP, 2006. Print.

---. "Introduction: Recovering from Recovery." The Future of Feminist Theory in Eighteenth-Century Studies (Special Issue). The Eighteenth Century: Theory and Interpretation 50.1 (Spring 2009): 1-11. MLA International Bibliography. Web. 10 Sept. 2010.

Schakel, Peter J. “Swift’s Remedy for Love: The ‘Scatological’ Poems.” Contemporary Studies of Swift’s Poetry. Eds. John Irwin Fischer and Donald C. Mell, Jr. Newark: U of Delaware P, 1981. 136-48. Print.

Swift, Jonathan. The Complete Poems. Ed. Pat Rogers. New Haven: Yale UP, 1983. Print.

Winch, Alison. “'The Nymph Grown Furious, Roar’d': Lady Mary Wortley Montagu's Response to Jonathan Swift’s 'The Lady’s Dressing Room.” Misogynism in Literature: Any Place, Any Time. Ed. Britta Zangen. New York: Lang, 2004. 71-88. Print.

Wilcoxon, Reba. “Pornography, Obscenity, and Rochester’s ‘Imperfect Enjoyment.”' Studies in English Literature, $1500-190015$ (1975): 375-90. Print.

Zeitz, Lisa M. and Peter Thoms. "Power, Gender and Identity in Aphra Behn’s 'The Disappointment.”' Studies in English Literature, 1500-1900 37.3 (Summer 1997): 501-16. Print. 